1912. (A. Lundberg and ...) "Neuere in den Hauptseehäften ausgeführte Bauten unter besonderer Berücksichtigung von Hafendämmen und Wellenbrechern. Verwendung des Eisen-Betons ; Mittel zur Sicherung seiner Haltbarkeit. Bericht" ("New harbour construction with particular reference to jetties and breakwaters in reinforced concrete" ). XIIter Internationaley Schiffahrthongress. Philadelphia, 1912. 11. Abt. 2. Mitt., $32 \mathrm{pp}$.

1912. (. . . and K. E. Petterson) "Berättelse över utförande av Stigbergskajens i Göteborg nybyggnad" ("Account of the construction of the new Stigberg quay in Gothenburg"). Göteborg, $80 \mathrm{pp}$.

1913. "Ekonomisk beräkning av pumpledningar och vattenledningsanläggningar" " Economical design of water supply works"). Tekn. Tidskr., 43:93-96.

1915. "Förslag till frihamn i Göteborg" ("A proposal for a free harbour in Gothenburg ").

1916. "Kaj- och jordrasen i Göteborg" ("The quay and earth slides in Gothenburg "). Tekn. Tidskr., $46: 133-138$

1918. "Kaj- och jordrasen i Göteborg" ("The quay and earth slides in Gothenburg "). Tekn. Tidskr., $48: 17-19$.

1918. "Konstruktion av bropelarna vid Södertälje kanal för Strömslinjen " ("The design of the piers for the Strömslinjen bridge, Södertälje Canal "). Tekn. Tidskr., 48:178-182.

1918, 1922, 1926, 1929. "Vattenbyggnadslaboratoriet" ("The Hydraulic Research Laboratory at the Royal Institute of Technology, Stockholm "). Mainly in Tekn. Tidskr.

1919. "Utredning beträffande kajbyggnaden för Trondhjems hamn" ("Design considerations for the quay in Trondhiem Harbour"). Tekn. Tidskr., 49:1-19.

1921. "Vågerosionsförsök. Utförda å Vattenbyggnadslaboratoriet vid Kungl. Tekniska Högskolan i anslutning till föreliggande förslag till Siljans reglering" ("Wave erosion tests performed at the Hydraulic Research Laboratory, KTH, Stockholm, in connexion with the proposal for the regulation of Lake Siljan"). Tekn. Tidskr., 51:325-329 and 337-338.

1921. (. . and L. von Post). "Utredning beträffande erosionsrisker genom particll reglering av Siljan " (" Investigation of the erosion risk arising from the partial regulation of Lake Siljan "). Stochholm, $72 \mathrm{pp}$.

1922. (As chairman 1919-1922.) "Statens Järnvägars Geotekniska Kommission: Slutbetänkande. 1914-1922" ("Swedish State Railways, Geotechnical Commission: Final Report"). Stockholm, 180 pp., 42 pp.

1926. "Jordstatiska beräkningar med friktion och kohesion (adhesion) för cirkulärcylindriska glidytor " (" Earth stability calculations assuming friction and cohesion on circular slip surfaces " Kungl. Vägoch Vattenbyggnadskårens 75 årsskrift. ("Royal Corps of Civil Engineers, 75th Anniversary Jubilee Publication"). Stockholm, pp. 79-127.

1927. "Erdstatische Berechnungen mit Reibung und Kohäsion (Adhäsion) und unter Annahme kreiszylindrischer Gleitflächen" ("F.arth stability ralculations assuming friction and cohesion on circular slip surfaces "). Berlin. (4th ed. 1948.)

1927. "Undersökning beträffande fallförluster i skyddsgrindar vid vattenkraftanläggningar " " Investigations of the head-loss at the intake screens of power plants "). Stockholm, 18 pp. (Ingenjörsvetensk.-akad. Hand1. No. 79.)

1929. "Jordstatiska beräkningar för vertikal belastning på horisontal mark under antagande av cirkulärcylindriska glidytor " " Earth stability calculations for vertical loads assuming circular slip surfaces ") Tekn. Tidskr., $59: 57-63$ and 75-79.

1933. (. . and E. Lindquist.) "Untersuchungen betr. die Abflussverhältnisse am Regulierwehr bei Vargön für die Wochenregulierung des Göta Älv" (Gedr. zur Weltkraft-Teilkonferenz in Stockholm unter der Besprechung der Gründung einer internationalen Kommission für das Wasserbauliche Versuchswesen). ("Investigations of the flow conditions at the regulation weir for the Göta River"). Stockholm, $43 \mathrm{pp}$

1933. (. . . and S. Johansson). "Untersuchungsmethoden zur Feststellung ob sich ein gegebenes Material für den Bau eines Erddammes eignet" (" Research methods for ascertaining the suitability of a given material for earth dam construction"). 1st Int. Congr. Large Dams, Stockholm, 1933, $3: 147-159$.

1936. "Calcnlations of the stability of earth dams." 2nd Int. Congr. Large Dams, Washington, 1936, $4: 445-462$

1943. "Ekonomiska problem inom vattenbyggnadstekniken" Avslutningsföreläsning vid Kungl. Tekniska Högskolan den 27 maj, 1943. " "Economical problems in the technique of hydraulic engineering". Valedictory Lecture at the Royal Institute of Technology, Stockholm.) Tekn. Tidskr., 73: 157. 163 .

\title{
ROLF H. GRAN OLSSON
}

It is with the deepest regret that we record the death on 3 August, 1957, of Dr-Ing. Rolf Gran Olsson of Norway.

Dr Gran Olsson was born in Vinger, near Oslo, on 9 August, 1903. He completed his studies in civil engineering in 1926 at the Technical University Charlottenhurg, Berlin, where in 1932 he also obtained his doctorate. During those 6 years, he received practical experience 
with various consulting engineers and contractors in Germany. In 1932 he was appointed lecturer, and in 1941 professor, at the Technical University, Trondheim, Norway.

Dr Gran Olsson was a most fascinating personality, with an extremely wide interest in theoretical problems in engineering science. He published more than one hundred papers covering such diverse fields as theory of elasticity, design of plates, shells, and suspension bridges, hydraulics, aerodynamics, and soil mechanics. His fundamental work on the consolidation of sediments has been presented in nine Papers published, partly in English, at various international conferences. At the time of his death, he was working on a major treatise, in which he intended to present a complete review of the process of consolidation.

During the past 10 years, Dr Gran Olsson showed a great interest in the development of soil mechanics in Norway, and he was a member of the committee whose work resulted in the establishment of the Norwegian Geotechnical Institute in 1951. Until his death he followed closely the work and progress at the Institute, and contributed greatly to its development with valuable ideas and suggestions.

\section{BIBLIOGRAPHY}

1948. "Forløpet av konsolideringen i et slamsjikt som funksjon av avleiringshastigheten." Tekn. ukeblad, $95: 591-96$, and $1949,96: 50-53$.

1949/50. "Rigorous solution of a differential equation in soil mechanics." Quart. J. Appl. Mech.,7:338-42.

1949. En enkel modell til forklaring av setningen ved stasjonaert leirsjikt. Tekn. ukeblad, 96:715-24 and $736-40$

1953. "Approximate solution of the progress of consolidation in a sediment." Proc. 3rd Int. Conf. Soil Mech., Zürich, $1: 38-42$.

1955, January. "Setninger av bygninger på leirgrunn." Published in the collection of lectures from the course in soil mechanics, by The Technical University of Norway. Mimeographed.

1955. "Uber Porenvolum und Porenziffer in der Erdbaumechanik und die verschieden dichte Packung von Kugeln." Det Kongelige norske videnskabers selskab. Fordhandlinger, 28 : 96-99, and 1956, $29: 22-23$.

1955. "Beziehungen zwischen klassischer Hydrodynamik und neuzeitlicher Erdbaumechanik insbesondere in der Theorie der Setzung von Tonschichten." Phys. Verhandlungen, 6: 153-54. 